\title{
A Study on the Training Mode of Accounting Innovation and Entrepreneurial Talents Based on "Internet +"
}

\author{
Runxiang Xu \\ (College of Economics and Management, Weifang University, Weifang 261061, China) \\ cyxrx@126.com
}

Keywords: Internet+; Accounting; Innovation and Entrepreneurship; Talent Cultivation

\begin{abstract}
The traditional training mode of accounting talents mainly studies the practical ability of students under the cooperation of industry-university-research institutes and ignores the creativity and personality of students. With the rapid development of Internet technology and the continuous deepening of the concept of innovation and entrepreneurship, the reform of accounting teaching model has a corresponding development platform and technical support. Accounting educators are faced with how to achieve the "Internet + " innovation and entrepreneurship accounting personnel training objectives, improve the professional level of students, and cultivate high-quality accounting talent. In this regard, this article takes innovation and entrepreneurship education as the background, accounting professional education as the research object, discusses how to establish an innovative accounting professional curriculum system, and makes full use of school-enterprise cooperation projects to increase student entrepreneurial opportunities. Improve the ability of accounting professionals to innovate and start businesses.
\end{abstract}

\section{Introduction}

It is difficult to meet the modern enterprise's demand for innovation and entrepreneurship ability of college graduates under the traditional education pattern. Using modern information technology, relying on the "Internet + " platform to study colleges and universities accounting education innovation and entrepreneurship training model to meet the modern enterprise's demand for graduates of college accounting. To investigate and analyze the current situation of the cultivation of innovative and entrepreneurial talents in accounting major in colleges and universities, and deeply grasp the prospect of the enterprise's human resource demand, so as to improve the innovation and entrepreneurship ability of accounting major students. For the purpose of serving enterprises, the use of information and communication technologies and the innovative education model of the Internet platform will provide a theoretical basis for how colleges and universities can cultivate innovative entrepreneurial talents more in line with business needs. Improving the employability of the accounting profession and cultivating the innovative thinking and entrepreneurial ability of accounting students are effective measures to cope with the current employment difficulties of college students. This article starts with the requirements of the innovation and entrepreneurship education concept for accounting personnel training model, and analyzes the construction of accounting professional curriculum system and the reconstruction of talent cultivation model based on the concept of innovation and entrepreneurship education.

The Idea of Innovation and Entrepreneurship Education Requires Accounting Talents Training Mode. In recent years, the number of graduates in the accounting profession has remained high, and employment has become the most important issue for graduates of the accounting profession. This requires the adjustment of training models for professional personnel, focusing on high-end skilled professionals as training objectives, starting from the employment requirements, the characteristics of the accounting profession itself and teaching reality, to better carry out teaching, and to achieve innovation and entrepreneurial personnel training objectives.

Focus on cultivating students' ability to innovate and entrepreneurship so that they have professional judgment

With the advancement of society and the rapid development of economy, the exchanges between 
various economic businesses become more and more complicated. This requires that students of accounting majors should not only improve their professional capabilities, but also have relevant written expression capabilities, innovation capabilities, and decision-making judgment ability, interpersonal communication ability and other comprehensive professional judgment ability, and students can analyze specific problems.

Respect students' personality development makes students have the spirit of lifelong learning

Innovation exists in the individuality. Individuals with positive personality, independent thinking, independent judgment, the exploration spirit of bold action and the spirit of initiative creation are all strong. Because of the characteristics of the profession itself, the students of accounting majors are more than rigorous and lack personality. Therefore, the emphasis on the development of students' personality is an important concept of innovation and entrepreneurship education in colleges and universities.

With the development of economy, knowledge is updated quickly, and both the enterprise system and the accounting system are faced with continuous reform and development. Accounting professionals must constantly absorb new knowledge, accept new systems, and acquire new skills. Facing the increasingly fierce competition in the talent market, students in the accounting profession should have a continuous learning spirit to meet the needs of social development.

Improve the overall quality of students so that they have comprehensive control capabilities

The accounting personnel of an enterprise not only provide accounting information for the enterprise, but also participate in the business decision-making of the enterprise. This requires the accounting professional personnel training, not only to enable students to master the professional knowledge, also should grasp such as finance, management, marketing and other economic or related professional knowledge, familiar with enterprise production operation, help enterprise to carry on the risk prevention.

The cultivation of talents for innovation and entrepreneurship seems to be a kind of quality training, focusing on improving the overall quality of students and satisfying the needs of society and enterprises for high-quality talents. Innovation and entrepreneurship education should aim at improving students' practical ability, creative ability, entrepreneurial ability and employability. Cultivate high-quality, skilled accounting professionals.

The Status Quo of Education in College Accounting. Lack of scientific innovation and entrepreneurship education system. At present, the cultivation of students' innovative ability is still in the primary stage of budding education in our country. Although the consciousness of innovation and entrepreneurship of college students in our country continues to be valued and promoted over the years, it is gradually improving greatly. But at present our country's college teaching curriculum system has not perfectly combined specific professional courses with innovation and entrepreneurship training programs. The dilemma is not to proceed from the perspective of accounting profession, to use the characteristics of the times to implement professional innovation and entrepreneurship. Therefore, from a performance perspective, it does not reflect the true innovation and entrepreneurial effect of the accounting profession.

Lack of professional and practical teaching. From the perspective of professional characteristics, the accounting profession is an application-oriented discipline with a focus on practicality. This requires students to be more familiar with the capabilities of accounting operations while mastering theoretical knowledge. However, judging from the current accounting talent cultivation mechanism in colleges and universities, there are also cases where academic knowledge is emphasized and practice learning is neglected. Although most colleges and universities in accounting professional training program will open up some practice-related training courses, such as manual accounts, accounting computerization, enterprise simulation management training, etc., but the students are often limited in the actual operation process Computer operations, step by step in accordance with the prescribed order, flow in form, not combined with real corporate business, which makes the role of theory and practice in accounting can't fully play out.

Teachers cannot meet the needs of students. In colleges and universities, students' initiative in learning is weak. Students often rely on their teachers to learn knowledge. The help and support of 
teachers is an important indicator of the success in entrepreneurship education. However, at present, the majority of colleges and universities in our country lacks "double-qualified" teachers. Teachers have little entrepreneurial experience. Even there are many young teachers who graduate from school to work directly at the school. Due to the lack of corporate work experience for teachers, understanding of accounting expertise only stays in the theoretical knowledge of the book, and lacks practical experience. Therefore, the teacher's teaching of students often can only be on paper. Teachers' academic qualifications and scientific research results are often the factors valued by the school. Actual ability and innovation ability of accounting students after they enter the company are ignored. After graduation, students cannot understand the interdisciplinary and field financial work because they only understand the theory. The empty and boring theoretical knowledge not only can't arouse students' enthusiasm for learning, but will abolish the student's desire to start a business, making students not only master theoretical knowledge of accounting, but also have no interest in accounting innovation and entrepreneurship.

The lack of entrepreneurial ability and innovation awareness of accounting students. Due to the limitations of the traditional teaching model of colleges and universities, the practical experience and professional ability of accounting students are limited, and the cultivation of innovation consciousness is also relatively backward, resulting in a weak position in entrepreneurial ability. The reasons for these situations are as follows: Firstly, the atmosphere is not enough, current school education pays more attention to theoretical education and lacks innovation and entrepreneurship education. Society generally believes that schools are the places to learn theoretical knowledge; Secondly, teachers and students pay less attention to innovation and entrepreneurship. Teachers are busy with theoretical research and theoretical knowledge. Students do not dare to practice in the future. In the end, there was not enough publicity. Many people had misunderstandings about accounting education in colleges and universities, and they believed that innovation and entrepreneurship education for students majoring in accounting was not an important aspect.

Construction of Training Mode for Innovative and Entrepreneurial Talents of Accounting Major Based on "Internet Plus". Clear "Internet + " Higher Education Innovation and Entrepreneurship Training Objective. Through on-the-spot investigation of the status quo of innovation and entrepreneurial talent cultivation of accounting majors, grasp the trend of human resource requirements of accountant professional counterparts, and understand the motivation and purpose of students under the new form of "Internet+". In-depth investigation and grasp of the situation of higher education innovation and entrepreneurship training and the close integration of the labor resources requirements of their counterpart companies. By serving counterpart enterprises through information and communication technologies and Internet platforms and reforming educational methods as starting points, the concept of "knowledge + competence + quality" is cultivated, the comprehensive talent cultivation mechanism for innovation and entrepreneurship in accounting is explored, and a professional teacher team is constructed. Innovate the "Internet + education" model, create an "Internet+ Accounting" and "Internet + Curriculum" online teaching platform, cultivate students' self-learning ability of "Internet+ Learning". Make "flipping classrooms" truly become a reality, and provide suggestions for the cultivation of innovation and entrepreneurial talents in colleges and universities.

"Internet + " background accounting professional classroom teaching education reform. In the teaching of accounting basic classroom teaching, teachers and students should give full play to the role of "dual-leadership and dual-subject", cultivate students' innovation-entrepreneurial ability, lead teacher-to-student exchanges, and give full play to students' enthusiasm, initiative, and passion for innovation and entrepreneurship. Teachers set up QQ groups for teaching classes and upload teaching plans, outlines, programs, courseware, and lesson plans. The students grouped themselves to discuss the content of the curriculum design, teachers conducted macro-level instruction, students made PPT courseware for the team, and took lectures on the rostrum and uploaded the video. Create an assignment column. Students place assignments in the job column. Students can participate in the evaluation while the teacher reads the report. Students' enthusiasm and initiative are fully utilized, and students' awareness of democratic management is cultivated. The class discussed the 
discussion of each group and the situation of the class. The teachers' commentary , demonstrations, on-line counseling, homework correction, these can improve the students' enthusiasm for learning. Student's usual explanation and work accounts for $25 \%$ of the total scores, social practice accounts for $25 \%$, and final exams account for $50 \%$, so as to achieve the effect of training students' organizational ability, innovative thinking ability, team communication and coordination ability, and professional development ability.

Strengthen Accounting and Training Teaching Reform. For practical training reform, the first is to investigate the training of accounting professionals and provide reference for the construction of a comprehensive talent cultivation system for innovation and entrepreneurship in the accounting profession. The second is to select professional counterpart companies, integrate grassroots skills positions and grassroots management posts, analyze job descriptions, and use information and communication technologies and Internet platforms to lay the foundation for the accounting professional innovation and entrepreneurship training system. The third, higher education to explore the use of information communication technology and the Internet platform to establish innovative entrepreneurship education of accounting professional talents with effective combination mechanism between the accounting professional counterparts, with students as the center, to serve the enterprise for the purpose, through the training of "two-way" to build network platform.

Using "Internet + " to build a new platform for school-enterprise cooperation that integrates with the accounting profession. The use of information and communication technologies and Internet platforms to solve the problem of higher education innovation and entrepreneurship training model to meet the needs of professional counterparts. Through investigating and analyzing the status quo of innovation and entrepreneurial talents in accounting majors in universities, we have established the idea of higher education serving the society and economy under the new environment, deeply grasped the prospects for corporate human resources requirements, and positioned the direction of human resources training for accounting majors in colleges and universities. Formulate a teaching plan matching with modern enterprise accounting talent training system. The use of information and communication technologies and the Internet platform to innovate educational models, to create a theoretical basis for the college students to become senior blue-collars and reserve cadres of modern enterprises, the accounting profession of colleges and universities is better served by economic and social undertakings.

\section{Summary}

At present, China's economic development has entered a new normal, and institutions, enterprises, and institutions all require large numbers of accounting professionals. Colleges and universities should adjust their training strategies according to the changes of the times, strengthen innovation and entrepreneurship education, and cultivate excellent accounting professionals. Therefore, the school must not only attach importance to students' innovation and entrepreneurship education, but also strengthen the construction of teachers' strength, increase the cooperation between schools and enterprises, realize the diversification of teaching models, and create favorable conditions for cultivating accountants who meet the needs of society.

\section{References}

[1] Vocational Accounting Professional Training Mode Reconstruction based on the Concept of Innovation and Entrepreneurship Education[J]. Pioneering with Science \& Technology Monthly, 2012.

[2] X H Zhao: The Design of Curriculum System for Innovation and Entrepreneurship in Accounting Major[J]. Higher Education Forum, 2014.

[3] Thébaud S: Status Beliefs and the Spirit of Capitalism: Accounting for Gender Biases in Entrepreneurship and Innovation[J]. Social Forces, 2015, 94(1):61.

[4] Y Sun, C D Hao and Y W Tang, et al: The Five Key Personalities of College Students and the Education of Entrepreneurship Tendency[J]. Heilongjiang Researches on Higher Education, 
2015.

[5] S Liu, H Zhang: Economics S O. Research on the Integrated Development of Strategic Entrepreneurship and Collaborative Innovation[J]. Communication of Finance \& Accounting, 2017.

[6] Wafa M: Typological Analysis of Non-technological and Technological Innovation Determinants in Tunisia[J]. Journal of Behavioural Economics Finance Entrepreneurship Accounting \& Transport, 2015, 3(2):71-75.

[7] Eesley C E, Miller W F: Impact: Stanford University's Economic Impact via Innovation and Entrepreneurship[J]. Social Science Electronic Publishing, 2013.

[8] Snyder C D, Hitt N P, Young J A: Accounting for Groundwater in Stream Fish Thermal Habitat Responses to Climate Change[J]. Ecological Applications, 2016, 25(5):1397-1419.

[9] Thouvenin P A, Dobigeon N, Tourneret J Y: Online Unmixing of Multitemporal Hyperspectral Images accounting for Spectral Variability[J]. IEEE Trans Image Process, 2016, 25(9):3979-3990.

[10] Christensen H B, Nikolaev V V: Wittenberg-Moerman R. Accounting Information in Financial Contracting: The Incomplete Contract Theory Perspective[J]. Journal of Accounting Research, 2016, 54(2):n/a-n/a.

[11]Z Zhang, H Chen: Accounting S O. Corporate Social Responsibility Disclosure and the Cost of Equity Capital:The Roles of Corporate Financial Transparency and Outside Governance Environment[J]. Journal of Nanjing University of Finance \& Economics, 2017.

[12]Leal-Millan A, Peris-Ortiz M, Leal-Rodríguez A L: Sustainability in Innovation and Entrepreneurship[J]. Innovation Technology \& Knowledge Management, 2018. 